Original

\title{
Biological evaluation of subgingivally placed direct resin composite materials
}

\author{
Cornelia Frese'), Diana Wolff(1), Tanja Krüger1), Hans J. Staehle1), \\ Christopher J. Lux ${ }^{2)}$, and Ralf Erber2) \\ 1)Department of Conservative Dentistry, University Hospital Heidelberg, Heidelberg, Germany \\ 2)Department of Orthodontics and Dentofacial Orthopaedics, University Hospital Heidelberg, \\ Heidelberg, Germany
}

(Received November 30, 2016; Accepted February 24, 2017)

\begin{abstract}
Placement of composite resin restorations in deep subgingival cavities can damage surrounding soft tissues. In addition, commonly used resin-based composites (RBCs) might interfere with wound healing and periodontal health. To clarify cellular interactions with RBCs, we used an MTT assay to investigate adhesion of primary human gingival fibroblasts and human osteoblasts (hFOB 1.19) on five RBC materials with and without surface modifications (alumina blasting with 50- or $110-\mu \mathrm{m} \mathrm{Al}_{2} \mathrm{O}_{3}$ ). In addition, high-performance liquid chromatography (HPLC) was used to determine release of resin monomers from RBCs after $1 \mathrm{~h}, 1$ day, and 7 days. As compared with tissue culture plastics (the control), cellular adhesion was significantly lower $(P<0.001)$ for human gingival fibroblasts and osteoblasts. Only minor, nonsignificant differences between individual RBCs were identified. HPLC analyses identified the release of three bifunctional methacrylates bisphenol A glycerolate dimethacrylate, triethylene glycol dimethacrylate, and diurethane dimethacrylate from RBCs and showed that monomer release increased between $1 \mathrm{~h}$ and 1 day but remained low. The present findings suggest that surface adhesion in the subgin-
\end{abstract}

Correspondence to Dr. Ralf Erber, Department of Orthodontics and Dentofacial Orthopaedics, University Hospital Heidelberg, Im Neuenheimer Feld 400, 69120 Heidelberg, Germany

Fax: +49-6221-56-5753

E-mail: ralf.erber@med.uni-heidelberg.de

J-STAGE Advance Publication: January 29, 2018

Color figures can be viewed in the online issue at J-STAGE.

doi.org/10.2334/josnusd.16-0827

DN/JST.JSTAGE/josnusd/16-0827 gival area is limited for the tested RBCs. Although residual monomer release was low for all tested RBCs, it might be sufficient to adversely affect cell adhesion.

Keywords: subgingival composite restorations; biological assessment; MTT assay; HPLC.

\section{Introduction}

In minimally invasive restorative dentistry, treatment indications were extended for direct resin composite restorations in the posterior region, and resin composite materials were recently reported to be the materials of choice (1). Long-term clinical observations showed that even large cavities encompassing three or more surfaces and cusps of load-bearing posterior teeth can be restored successfully with minimally invasive direct restoration techniques (2-5). However, direct restoration of deep proximal defects beyond the cemento-enamel junction (CEJ) requires elaborate treatment techniques and considerable operator skill. Previous reports described several treatment protocols, all of which favored idealization of the cavity as the first step of direct restorative technique and subsequent fabrication of a direct or indirect restoration. The approaches are called for instance sandwich technique $(6,7)$, supragingival relocation of subgingival margins (8-11), margin elevation technique (12), proximal box elevation technique $(13,14)$, and R2 technique (15). If moisture control in the deep subgingival area is possible, the proximal box is usually elevated, and the cavity is idealized by direct modeling of resin-based composite (RBC) materials. The idealized cavity allows for simplified application of a rubber dam 
Table 1 Characteristics of dental resin-based composites (RBCs) used in this study

\begin{tabular}{|c|c|c|c|}
\hline Material/Lot & Classification & Resin matrix & Manufacturer \\
\hline $\begin{array}{l}\text { Tetric Evo Ceram } \\
\text { Lot } 53247\end{array}$ & Nanohybrid RBC & $\begin{array}{l}\text { Bis-GMA, UDMA, Ethoxylated } \\
\text { Bis-EMA }\end{array}$ & $\begin{array}{l}\text { Ivoclar Vivadent AG, Schaan, } \\
\text { Liechtenstein }\end{array}$ \\
\hline $\begin{array}{l}\text { Tetric Ceram } \\
\text { Lot R02783 }\end{array}$ & Hybrid RBC & Bis-GMA, UDMA, TEGDMA & $\begin{array}{l}\text { Ivoclar Vivadent AG, Schaan, } \\
\text { Liechtenstein }\end{array}$ \\
\hline $\begin{array}{l}\text { Dyract Xtra } \\
\text { Lot } 1104001174\end{array}$ & Compomer & $\begin{array}{l}\text { UDMA, TCB-resin, TEGDMA, } \\
\text { Trimethacrylate resin }\end{array}$ & $\begin{array}{l}\text { Dentsply De Trey GmbH, } \\
\text { Konstanz, Germany }\end{array}$ \\
\hline $\begin{array}{l}\text { Filtek Supreme XTE } \\
\text { Lot N224828 }\end{array}$ & Nano RBC & $\begin{array}{l}\text { Bis-GMA, UDMA, TEGDMA, } \\
\text { PEGDMA, Bis-EMA }\end{array}$ & 3M ESPE AG, Seefeld, Germany \\
\hline $\begin{array}{l}\text { Admira } \\
\text { Lot } 1127300\end{array}$ & Ormocer-based RBC & $\begin{array}{l}\text { ORMOCER-resin, Bis-GMA, } \\
\text { UDMA, TEGDMA }\end{array}$ & VOCO, Cuxhaven, Germany \\
\hline
\end{tabular}

and use of a sectional matrix system for direct anatomical rehabilitation of tooth form and shape (15) or facilitated insertion of an indirect restoration $(13,14)$. Nevertheless, surrounding soft and hard tissues are adversely affected by finishing and polishing of the subgingival margins of the composite resin restoration.

Several studies have reported cytotoxic substances in dental resin composites, the most frequently detected of which are the bifunctional methacrylates bisphenol A glycerolate dimethacrylate (Bis-GMA), triethylene glycol dimethacrylate (TEGDMA), and diurethane dimethacrylate (UDMA), and 2-hydroxyethyl methacrylate $(16,17)$. RBCs placed in the subgingival area might release residual monomers that can interfere with wound healing after subgingival placement of a composite resin. However, few studies of RBCs have evaluated monomer release and the effects on target cells in the subgingival area, and, to the best of our knowledge, no study compared five different RBC materials and their effects on fibroblasts and osteoblasts in the subgingival area. We examined the biocompatibility of RBCs with cell types of the subgingival area by comparing adhesion of human gingival fibroblasts (HGFs) and osteoblasts on five types of RBCs with various surface modifications. We attempted to identify the optimal RBC material and surface modification for use in the subgingival area and to determine if residual monomer release interferes with cell adhesion.

\section{Materials and Methods}

We used an in vitro test of cellular adhesion to evaluate the biological effects of composite restorations beyond the CEJ. Primary HGFs and a human osteoblast cell line
(hFOB 1.19) were used to assess adhesion on five types of composite materials with three different surface modifications. The presence of residual monomers might affect the recovery of biological structures after restorative treatment. Therefore, we measured the release of resin monomers from the composite materials after leaching for $1 \mathrm{~h}, 1$ day, and 7 days.

\section{Assessment of cell adhesion}

The five RBC materials used in this study are listed in Table 1.

\section{Specimen preparation}

In a class II safety cabinet, under sterile conditions, specimens for each RBC ( $n=27$ each) were fabricated by using prefabricated autoclaved round silicon molds (diameter 5 $\mathrm{mm}$, height $1.7 \mathrm{~mm}$, total surface area $66 \mathrm{~mm}^{2}$ ). The resin composite material was pressed into the molds and flattened gently with a sterile microscope slide and then light polymerized (SmartLite PS, Dentsply DeTrey GmbH, Konstanz, Germany; wavelength 450-490 nm, $890 \mathrm{mW/}$ $\mathrm{cm}^{2}$ ) according to the manufacturer's instructions. The oxygen inhibition layer was removed with ethanol, and the specimens were rinsed $(3 \times 10 \mathrm{~min})$ with sterile distilled water. The surface of specimens was then either left untreated ( $n=9)$, alumina blasted with $50-\mu \mathrm{m} \mathrm{Al}_{2} \mathrm{O}_{3}$ (KaVo, Biberach, Germany; $n=9$ ), or alumina blasted with $110-\mu \mathrm{m} \mathrm{Al}_{2} \mathrm{O}_{3}(n=9)$.

\section{MTT Assay}

Cell adhesion of primary HGFs or hFOB 1.19 on resin composite surfaces was determined with the MTT assay. Gingival tissue for establishing HGFs was obtained from 
patients who provided written informed consent, and harvesting of these tissues was approved by the Medical Ethics Committee of the University of Heidelberg (Approval number: 80/94). HGFs were established from explant cultures of gingival connective tissues, as previously described (18). The human fetal osteoblast cell line hFOB 1.19 (CRL-11372) was obtained from ATCC (Wesel, Germany).

Composite specimens were placed in 96-well plates, and 10,000 cells per well were seeded in $200 \mu \mathrm{L}$ of culture medium with stable glutamine (DME medium; Biochrom, Berlin, Germany) supplemented with $10 \%$ fetal calf serum (Biochrom), antibiotics, and antimycotics for $24 \mathrm{~h}\left(37^{\circ} \mathrm{C}, 5 \% \mathrm{CO}_{2}\right)$. To assess cell adhesion only on the specimens, these were gently removed with Dumont forceps (\#7, tip size $0.07 \times 0.04 \mathrm{~mm}$, F.S.T., Heidelberg, Germany), without touching the upper surface, and transferred to a new well prefilled with $100 \mu \mathrm{L}$ of supplemented DMEM. MTT assays were performed according to the manufacturer's protocol (Promega, Mannheim, Germany). Optical density (OD) was measured with a multiwell reader (GeniosPro, Tecan, Crailsheim, Germany) at a wavelength of $570 \mathrm{~nm}$. To assess relative cell adhesion, the results were calculated as the ratio between the ODs of the test specimens as compared with the ODs of the respective positive controls (HGF or hFOB 1.19 grown on tissue culture plastic (TCP) surfaces in supplemented DMEM) and corrected for the surface area of the test specimen. Cell adhesions on RBCs are expressed as percentages relative to TCP (TCP $=100 \%)$. All experiments were performed in triplicate and repeated three times.

\section{Scanning electron microscopic imaging}

To analyze the surface texture of RBCs, specimens were fixed to a special holder for observation with a scanning electron microscope (SEM), air-dried in a desiccator at approximately $20 \mathrm{hPa}$, and sputter-coated with a 30-nm layer of gold (S150, Edwards, Marburg, Germany). To evaluate surface texture, specimens were magnified $(\times 150)$ in the SEM (1810D, Amray, Bedford, MA, USA).

\section{Assessment of cellular morphology of attached cells} Before seeding on the composite specimen $(10,000$ cells/well in 96-well plates), cells were labeled with the fluorescent vital dye DiI (1'-dioctadecyl-3,3,3',3'tetramethylindocarbocyanine perchlorate, $3 \mu \mathrm{M}$ in PBS, $20 \mathrm{~min}$ at $37^{\circ} \mathrm{C}$; Thermo Fisher Scientific, Dreieich, Germany). After 24 -h incubation $\left(37^{\circ} \mathrm{C}, 5 \% \mathrm{CO}_{2}\right)$, the cells were mounted with Vectashield mounting medium (Vector Labs, Burlingame, CA, USA). Adherent cells were examined with fluorescence microscopy. Microphotographs were obtained by using a Leica DMRE microscope equipped with a digital camera (DFC300 FX, Leica, Bensheim, Germany). Image acquisition and processing were performed with the Leica application suite software (Leica, Bensheim, Germany).

\section{Assessment of monomer release}

We used high-performance liquid chromatography (HPLC) to assess release of Bis-GMA, TEGDMA, and UDMA from composite specimens. Specimens $(n=3$ per RBC) were incubated in $1 \mathrm{~mL}$ of an ethanol-water (75\%:25\%) mixture (19) (approved by the US Food and Drug Administration) for $1 \mathrm{~h}, 24 \mathrm{~h}$, or 7 days. Qualitative and quantitative analysis of eluates was done with HPLC by using an Äkta Purifier (GE Healthcare, Freiburg, Germany) with a connected UV-900 detector. Accucore C18 columns $(100 \times 3 \mathrm{~mm}$, particle size $2.6 \mu \mathrm{m})$ and Accucore Solid Core Defender $(10 \times 3 \mathrm{~mm}$; particle size $2.6 \mu \mathrm{m}$ ) pre-columns (both Thermo Scientific, Dreieich, Germany) were used for analysis, and $10 \mu \mathrm{L}$ of the eluates in $40-\mu \mathrm{L}$ phase A were injected. The gradient at time 0 min was $100 \%$ phase $\mathrm{A}(20 \%$ acetonitrile in water) and $0 \%$ phase B (90\% acetonitrile in water), and the gradient at time 40 min was $100 \%$ phase B and $0 \%$ phase A. Flow rate was $0.5 \mathrm{~mL} / \mathrm{min}$. The elution profile was monitored at detection wavelengths of 205 and $280 \mathrm{~nm}$. Standard calibration curves were made by analyzing known concentrations of resin monomers in ethanol-water (75:25) (Bis-GMA [lot no. MKBH5136V], TEGDMA [lot no. STBC4723V], and UDMA [lot no. MKBC6935], all purchased from Sigma Aldrich, Steinheim, Germany) (20). Linear regression analysis (MS Excel, Unterschleissheim, Germany) based on the peak area at the corresponding retention times was used to calculate monomer concentrations in each sample. The detection limits were $3.8 \mathrm{nmol} / \mathrm{mL}$ for bis-GMA, 4.7 $\mathrm{nmol} / \mathrm{mL}$ for TEGDMA, and $4.5 \mathrm{nmol} / \mathrm{mL}$ for UDMA (19). Because leaching of resin monomers depends on the composite surface area $\left(66 \mathrm{~mm}^{2}\right)$, data are presented in $\mathrm{nmol} / \mathrm{mm}^{2}(21)$.

\section{Statistical analysis}

Results are presented as mean \pm standard deviation. Differences between groups were compared with the Mann-Whitney $U$ test. All statistics were performed by using SigmaStat software (SPSS Inc., Chicago, IL, USA). A $P$ value of less than 0.05 was considered to indicate statistical significance. 


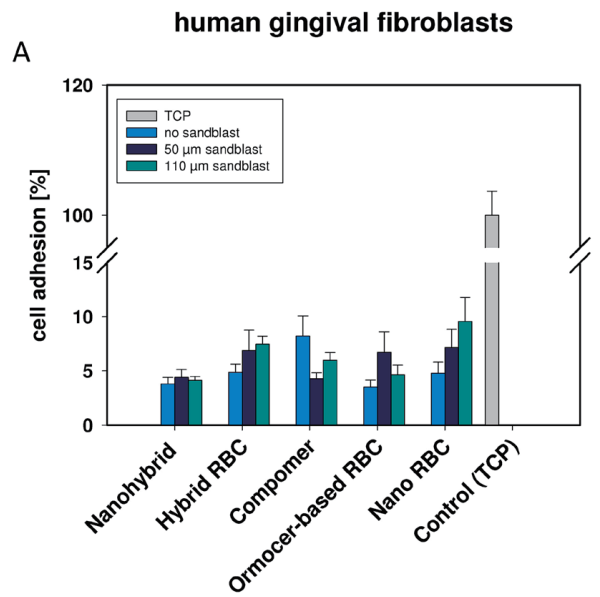

human fetal osteoblasts (hFOB 1.19)

B

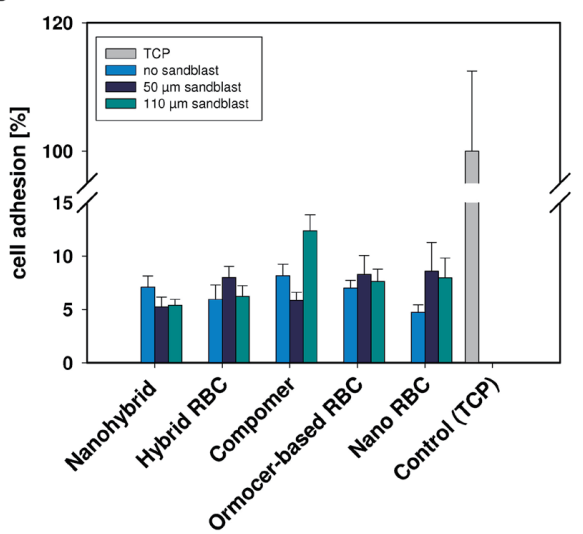

Fig. 1 Cell adhesion (\%) of human gingival fibroblasts (HGFs) (A) and human fetal osteoblasts 1.19 (hFOBs) (B) on five resinbased composites (RBCs). As compared with tissue culture plastic (TCP; the positive control) HGF cell adhesion was significantly lower on all five RBCs and for all surface modifications $(P<$ $0.001)$.

\section{Cell adhesion}

\section{Results}

The results of the cell adhesion assays are shown in Table 2 and Fig. 1A and B. The Mann-Whitney $U$ test showed that cell adhesion was significantly lower on all five RBC materials and for all surface modifications than for TCP, the positive control $(P<0.001)$.

\section{Cell adhesion of HGFs}

Cell adhesion values for HGFs relative to TCP, which was defined as $100 \%$ adhesion, are shown in Table 2 (upper part) and illustrated in Fig. 1A. Mean $( \pm$ SEM) cell adhesion was $3.5 \%$ (2.0) to $8.2 \%$ (5.6) for untreated surfaces, $4.3 \%$ (1.7) to $7.2 \%$ (5.0) for surfaces alumina blasted with $50-\mu \mathrm{m} \mathrm{Al}_{2} \mathrm{O}_{3}$, and $4.5 \%$ (1.1) to $9.6 \%$ (6.6) for surfaces alumina blasted with $110-\mu \mathrm{m} \mathrm{Al}_{2} \mathrm{O}_{3}$. On specimens without surface modifications, cell adhesion decreased in the following order: compomer $>$ hybrid

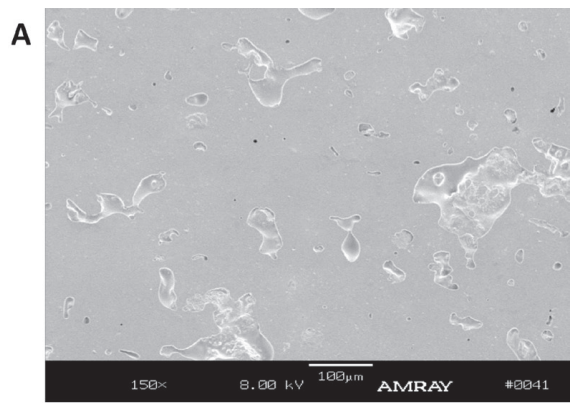

B

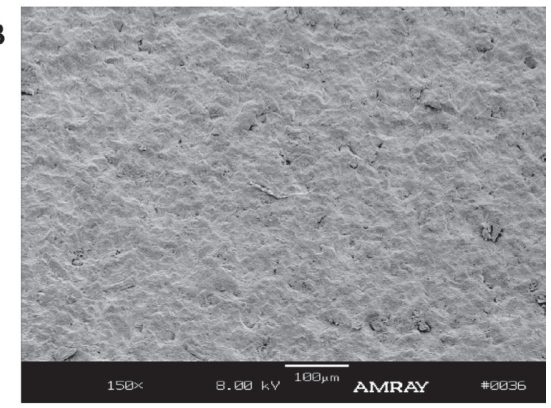

c

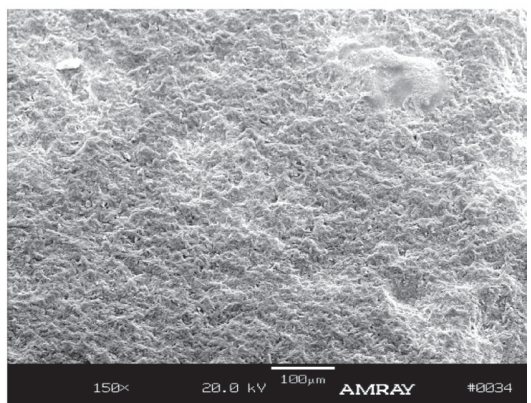

Fig. 2 Scanning electron microscopic images of surface texture. A. untreated resin-based composite (RBC) specimen (RBC pressed against a sterile microscope slide); B. RBC specimen after alumina blasting with $50-\mu \mathrm{m}_{2} \mathrm{O}_{3}$; C. RBC specimen after alumina blasting with $110-\mu \mathrm{m} \mathrm{Al}_{2} \mathrm{O}_{3}$.

$\mathrm{RBC}>$ nano $\mathrm{RBC}>$ nanohybrid $\mathrm{RBC}>$ ormocer-based RBC. Alumina blasting of surfaces with $50-\mu \mathrm{m} \mathrm{Al}_{2} \mathrm{O}_{3}$ changed cell adhesion on RBC specimens, which decreased in the following order: nano $\mathrm{RBC}>$ hybrid $\mathrm{RBC}>$ ormocer-based $\mathrm{RBC}>$ nanohybrid $\mathrm{RBC}>$ compomer. Further changes were observed after alumina blasting with $110-\mu \mathrm{m} \mathrm{Al}_{2} \mathrm{O}_{3}$, as indicated by the following decreasing order: nano $\mathrm{RBC}>$ hybrid $\mathrm{RBC}>$ compomer $>$ ormocer-based $\mathrm{RBC}>$ nanohybrid $\mathrm{RBC}$. The differences between RBCs and between surface modifications were not significant.

\section{Cell adhesion of $h F O B 1.19$}

Cell adhesion of hFOB 1.19 was compared with TCP adhesion, which was defined as $100 \%$. The findings are shown in the lower half of Table 2 and illustrated in Fig. $2 \mathrm{~B}$. As compared with TCP, mean $( \pm \mathrm{SEM})$ adhesion for hFOB 1.19 was $4.8 \%$ (2.1) to $8.2 \%$ (3.2) for untreated 
Table 2 Mean values ( \pm standard error of the mean) for cell adhesion (\%) of human gingival fibroblasts (HGF) and human fetal osteoblasts 1.19 (hFOBs) on five resin-based composites (RBCs)

\begin{tabular}{lccc}
\hline & & $\mathrm{HGF}$ & \\
Material & No alumina blasting & $50-\mu$ m alumina blasting $\left(\mathrm{Al}_{2} \mathrm{O}_{3}\right)$ & $110-\mu$ m alumina blasting $\left(\mathrm{Al}_{2} \mathrm{O}_{3}\right)$ \\
\hline Nanohybrid RBC & $3.82 \pm 1.74$ & $4.41 \pm 2.20$ & $4.51 \pm 1.05$ \\
Hybrid RBC & $4.87 \pm 2.27$ & $6.88 \pm 5.66$ & $7.46 \pm 2.20$ \\
Compomer & $8.21 \pm 5.58$ & $4.28 \pm 1.67$ & $6.00 \pm 2.11$ \\
Ormocer-based RBC & $3.52 \pm 1.96$ & $6.73 \pm 5.66$ & $4.66 \pm 2.65$ \\
Nano RBC & $4.80 \pm 3.10$ & $7.17 \pm 5.01$ & $9.58 \pm 6.64$ \\
Control (TCP) & $100 \pm 3.67$ & $100 \pm 3.67$ & $100 \pm 3.67$ \\
\hline & & & \\
Material & hFOB & $110-\mu$ alumina blasting $\left(\mathrm{Al}_{2} \mathrm{O}_{3}\right)$ \\
\hline Nanohybrid RBC & No alumina blasting & $50-\mu$ malumina blasting $\left(\mathrm{Al}_{2} \mathrm{O}_{3}\right)$ & $5.41 \pm 1.59$ \\
Hybrid RBC & $7.08 \pm 3.13$ & $5.22 \pm 2.81$ & $6.23 \pm 2.97$ \\
Compomer & $5.95 \pm 4.03$ & $8.00 \pm 3.02$ & $12.34 \pm 4.56$ \\
Ormocer-based RBC & $8.16 \pm 3.24$ & $5.85 \pm 2.31$ & $7.63 \pm 3.41$ \\
Nano RBC & $7.01 \pm 2.13$ & $8.28 \pm 5.35$ & $7.98 \pm 5.49$ \\
Control (TCP) & $4.75 \pm 2.07$ & $8.59 \pm 8.04$ & $100 \pm 12.49$ \\
\hline
\end{tabular}

TCP: tissue culture plastic.

surfaces, $5.2 \%(2.8)$ to $8.6 \%(8.0)$ for surfaces alumina blasted with $50-\mu \mathrm{m} \mathrm{Al}_{2} \mathrm{O}_{3}$, and $5.4 \%$ (1.6) to $12.3 \%$ (4.6) for surfaces alumina blasted with $110-\mu \mathrm{m} \mathrm{Al}_{2} \mathrm{O}_{3}$. Cell adhesion decreased in the following order on unmodified surfaces: compomer $>$ nanohybrid $\mathrm{RBC}>$ ormocer-based $\mathrm{RBC}>$ hybrid $\mathrm{RBC}>$ nano $\mathrm{RBC}$. Alumina blasting with $50-\mu \mathrm{m} \mathrm{Al}_{2} \mathrm{O}_{3}$ led to the following decreasing order of cell adhesion: nano $\mathrm{RBC}>$ ormocer-based $\mathrm{RBC}>$ hybrid $\mathrm{RBC}>$ compomer $>$ nanohybrid RBC. Alumina blasting with $110-\mu \mathrm{m} \mathrm{Al}_{2} \mathrm{O}_{3}$ altered cell adhesion and led to the following decreasing order: compomer $>$ nano $\mathrm{RBC}>$ ormocer-based $\mathrm{RBC}>$ hybrid $\mathrm{RBC}>$ nanohybrid $\mathrm{RBC}$. The differences between materials and between surface modifications in HGF and hFOB adhesion were small and nonsignificant. Therefore, we were unable to identify the best RBC material or surface modification for application in the subgingival area.

\section{SEM imaging of composite surfaces}

The results of SEM imaging are shown in Fig. 2A-C. Figure 2A shows the surface texture of RBC without treatment (i.e., RBC pressed against a sterile microscope slide), Fig. 2B shows the surface texture after alumina blasting with $50-\mu \mathrm{m} \mathrm{Al}_{2} \mathrm{O}_{3}$, and Fig. $2 \mathrm{C}$ shows the surface texture after alumina blasting with $110-\mu \mathrm{m} \mathrm{Al}_{2} \mathrm{O}_{3}$. As compared with 50- $\mu \mathrm{m} \mathrm{Al}_{2} \mathrm{O}_{3}$ blasting, 110- $\mu \mathrm{m} \mathrm{Al}_{2} \mathrm{O}_{3}$ blasting resulted in deeper cavities and qualitatively greater surface roughness.

\section{Assessment of cellular morphology of attached cells} Cellular morphology of attached cells was representatively assessed on the nanohybrid RBC (Tetric Evo Ceram, Table 1). Direct evaluation of cellular morphology by
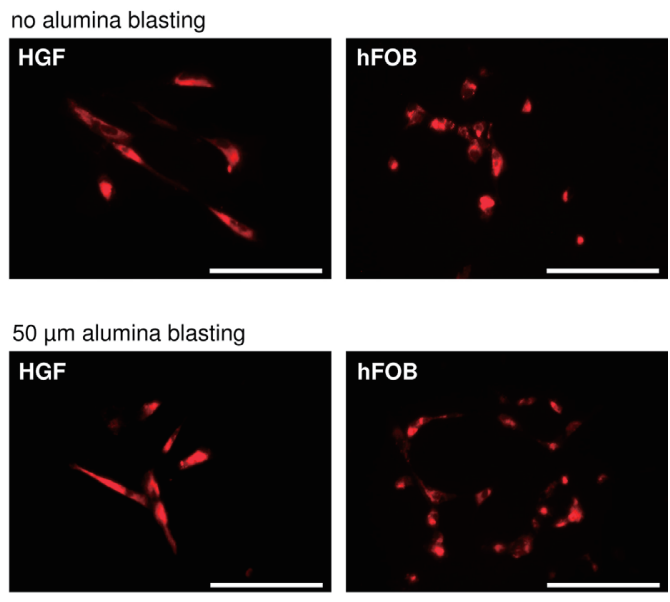

$110 \mu \mathrm{m}$ alumina blasting
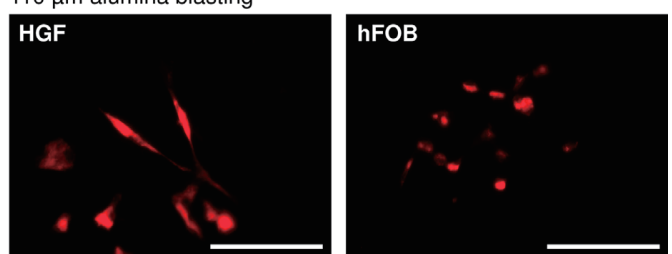

Fig. 3 Assessment of cellular morphology. Representative images of cells grown on Tetric Evo Ceram. Cells were labeled with the vital dye DiI (1,1'-dioctadecyl-3,3,3',3'-tetramethylindocarbocyanine perchlorate, red color). The characteristic cellular morphologies of human gingival fibroblasts and osteoblasts were preserved on resin-based composites. Surface modifications had no obvious effect on cell morphology. Bar $=20 \mu \mathrm{m}$.

light microscopy was not possible because of the limited transparency of the RBC; we therefore labeled cells with the fluorescent vital dye DiI, which is well retained in cell membranes and stains the entire cell without affecting viability or proliferation. As expected, only a few HGFs and hFOBs were attached to the RBC specimen (Fig. 3). 
Table 3 Results of HPLC analysis of release kinetics of resin monomers at 1 h, $24 \mathrm{~h}$, and 7 days of monomer leaching

\begin{tabular}{llccc}
\hline Material & Incubation time & UDMA $\left(\mathrm{nmol} / \mathrm{mm}^{2}\right)$ & Bis-GMA $\left(\mathrm{nmol} / \mathrm{mm}^{2}\right)$ & TEGDMA $\left(\mathrm{nmol}^{2} \mathrm{~mm}^{2}\right)$ \\
\hline Nanohybrid composite & $1 \mathrm{~h}$ & 3.00 & 2.50 & n.d. \\
& 1 day & 6.98 & 6.25 & n.d. \\
n.d. \\
Hybrid composite & 7 days & 8.06 & 7.23 & 1.55 \\
& $1 \mathrm{~h}$ & 2.14 & 2.60 & 2.36 \\
Nanocomposite & 7 day & 5.06 & 6.41 & 3.27 \\
& 7 days & 6.84 & 8.14 & 0.40 \\
Ormocer & 1 day & 1.32 & 0.99 & 0.82 \\
& 7 days & 2.99 & 2.02 & 0.62 \\
& 1 h & 2.45 & 1.67 & 0.52 \\
Compomer & 1 day & 1.38 & 1.56 & 1.00 \\
& 7 days & 3.18 & 3.19 & 0.73 \\
& 1 h & 2.65 & 2.75 & 1.20 \\
Bis-GMA: bisphenol-A-glycerolate dimethacrylate; TEGDMA: triethylene glycol dimethacrylate; UDMA: diurethane dimethacrylate. n.d.
\end{tabular}

$=$ not detected.

HGFs had a typical fibroblastoid morphology, i.e., an elongated spindle shape and extended cellular protrusions. Differences in cellular morphology were not evident between surface modifications generated by alumina sandblasting. hFOBs showed an osteoblastlike phenotype, namely, smaller, polygonal cells with limited protrusions. Qualitative analysis by fluorescence microscopy showed that cells grown on different surface modifications did not exhibit morphological differences. Although cell adhesion on RBCs was limited in the present study, cell morphology was generally normal for both cell types and all surface modifications.

\section{Residual monomer release}

The results of HPLC analyses are shown in Table 3. HPLC identified the leachable monomers UDMA, Bis-GMA, and TEGDMA. For all RBCs, analysis of release kinetics showed increased monomer release (UDMA, Bis-GMA, and TEGDMA) between $1 \mathrm{~h}$ and 1 day. Between 1 day and 7 days, increases in UDMA and Bis-GMA could only be detected for the nanohybid and hybrid RBCs. An increase in UDMA between 1 day and 7 days was detected for the compomer material. The nano RBC and the ormocer-based RBC showed no increase in UDMA, Bis-GMA, or TEGDMA between 1 day and 7 days.

At all time points, UDMA release decreased in the following order: nanohybrid $\mathrm{RBC}>$ hybrid $\mathrm{RBC}>$ ormocer-based $\mathrm{RBC}>$ nano $\mathrm{RBC}>$ compomer. The nanohybrid RBC leached the highest amounts of UDMA ( $1 \mathrm{~h}: 3.00 \mathrm{nmol} / \mathrm{mm}^{2}, 1$ day: $6.98 \mathrm{nmol} / \mathrm{mm}^{2}, 7$ days: 8.06 $\mathrm{nmol} / \mathrm{mm}^{2}$ ). Bis-GMA release at all investigated time points decreased in the following order: hybrid $\mathrm{RBC}>$ nanohybrid $\mathrm{RBC}>$ ormocer-based $\mathrm{RBC}>$ nano $\mathrm{RBC}$. The compomer does not contain Bis-GMA. The hybrid RBC leached the highest amounts of Bis-GMA (1 h: $2.60 \mathrm{nmol} /$ $\mathrm{mm}^{2}, 1$ day: $6.41 \mathrm{nmol} / \mathrm{mm}^{2}, 7$ days: $8.14 \mathrm{nmol} / \mathrm{mm}^{2}$ ) and the highest amounts of TEGDMA ( $1 \mathrm{~h}: 1.55 \mathrm{nmol} / \mathrm{mm}^{2}, 1$ day: $2.36 \mathrm{nmol} / \mathrm{mm}^{2}, 7$ days: $3.27 \mathrm{nmol} / \mathrm{mm}^{2}$ ). TEGDMA release for the ormocer-based RBC and compomer was heterogeneous. However, at all time points, the hybrid RBC released the highest amounts of TEGDMA and the nano $\mathrm{RBC}$ released the lowest amounts. The nanohybrid RBC does not contain TEGDMA.

We therefore concluded that RBCs release composite monomers that might interfere with cell physiology and thus slow wound healing.

\section{Discussion}

The biological effects of deep and insufficient restorative margins below the CEJ are believed to cause overgrowth of periodontal pathogens, inflammation, and destruction of soft and hard tissue. Although special restorative techniques, advanced operator skills (22), and oral hygiene training are important, selection of the appropriate material for restoring the apical part of deep proximal cavities might be essential for the healing and maintenance of biological structures. Previous studies of glass-ionomer cements $(6,23)$, polyacid-modified resin composite materials $(7,24)$, and methacrylate-based composite systems (25) described their effects on long-term durability, marginal qualities, bond strength, and development of secondary caries. Because of their long-term success, composite resin materials are the material of choice for restoration of deep subgingival defects. However, the effects of RBCs on biological structures in the subgingival area has not been investigated. The present simple 
in vitro study sheds light on biological interactions in the subgingival area.

We focused on evaluating the effects of $\mathrm{RBC}$ restorations on actual intraoral targets, namely, the cells that are in close contact with such restorations-gingival fibroblasts and osteoblasts. Cell adhesion was measured by determining the number of viable cells with MTT assays. Five RBC types were used to assess subgingival cell adhesion on RBC surfaces with or without modifications. In vitro adhesion of fibroblasts and osteoblasts on these RBC types was minimal and did not significantly differ in relation to RBC type. Surface modification by alumina blasting with $50-\mu \mathrm{m}$ and $110-\mu \mathrm{m} \mathrm{Al}_{2} \mathrm{O}_{3}$ also had no significant effects on cell adhesion (Table 2; Fig. 1A, B). Surface modification by alumina blasting was chosen in order to simulate subgingival finishing techniques with diamond burs of different grit size. Standardized surface roughening with alumina blasting was considered more advantageous than manual roughening with diamond burs.

HPLC analyses of RBC leaching identified the monomers UDMA, Bis-GMA, and TEGDMA. The presence of residual monomers might affect healing of biological structures after restorative treatment. Therefore, we measured release of resin monomers from composite material after leaching for $1 \mathrm{~h}, 1$ day, and 7 days, the latter representing the time of wound healing (Table 3). The interval between $1 \mathrm{~h}$ and $24 \mathrm{~h}$ was chosen because elution of leachable components is asymptotic: most is released within the first hours $(20,26,21)$. A limited maximal incubation period of 7 days was chosen because a recent meta-analysis of 22 studies showed that monomer release from $\mathrm{RBC}$ materials was completed within 1 week (21). Extraction of leachable components in $1 \mathrm{~mL}$ of an ethanol-water (75\%:25\%) mixture does not reflect conditions in the oral cavity, as alcoholic solutions are good solvents for methacrylates $(21,19)$. Although hydrophilic polymeric compounds are less soluble in artificial or original saliva than in ethanolwater mixtures, organic solvents allow for identification and assessment of release kinetics of residual monomers, as was desired in the present study (21). Levels of the present residual monomers were consistent with those in previous reports. Bis-GMA release in organic solvents was reported to be 1.4 to $9.5 \mathrm{nmol}$, calculated per volume or surface (21). Eluted monomers from RBCs such as Bis-GMA, UDMA, and TEGDMA had cytotoxic effects on human oral cells $(27,28)$. Thus, our observation of minimal adhesion of HGFs and osteoblasts on RBC specimens might in part be attributable to the cytotoxic effects of leached resin monomers or other leachable components in composites. This hypothesis is supported by our finding that cells attached to RBCs did not have atypical or impaired cellular morphologies.

The present simple in vitro tests are the first attempt to clarify cell-composite interactions in the subgingival area. Clearly, further improvements and studies are needed in order to test $\mathrm{RBC}$ materials in relation to monomer composition, cell interactions and monomer release in aqueous solvents. Recent studies have reported technological improvements in composite resin. Of particular interest are antibacterial additives that might reduce secondary caries and biofilms and enhance remineralization of teeth (29-31). Thus, material-induced reactions should be expected when margins beyond the CEJ are required. In addition, future studies should continue to evaluate RBC materials, to determine the optimal resin matrix composition and identify bioactive additives for clinical application in deep cavities with margins beyond the CEJ.

In conclusion, we found that subgingival cell adhesion was limited for the tested RBC materials and surface modifications. Although residual monomer release from RBCs was low, it might be sufficient to adversely affect subgingival cell adhesion. However, in vitro methods have a limited ability to replicate clinical conditions. If future indications for subgingival resin composite restorations are extended, clinical and in vitro studies should examine improvement in composite-cell interactions and development of new bioactive RBC materials.

\section{Acknowledgments}

We thank Dr. Ralf Bischoff of the German Cancer Research Center, Heidelberg, for providing technical equipment and expert advice on HPLC.

\section{Conflict of interest}

The authors declare that they have no affiliations with or involvement in any organization with a financial or non-financial interest in the subject matter or materials discussed in this manuscript.

\section{References}

1. Lynch CD, Opdam NJ, Hickel R, Brunton PA, Gurgan S, Kakaboura A et al. (2014) Guidance on posterior resin composites: Academy of Operative Dentistry--European section. J Dent 42, 377-383.

2. da Rosa Rodolpho PA, Cenci MS, Donassollo TA, Loguercio AD, Demarco FF (2006) A clinical evaluation of posterior composite restorations: 17-year findings. J Dent 34, 427-435.

3. Opdam NJ, Bronkhorst EM, Loomans BA, Huysmans MC (2010) 12-year survival of composite vs. amalgam restorations. J Dent Res 89, 1063-1067. 
4. Demarco FF, Correa MB, Cenci MS, Moraes RR, Opdam NJ (2012) Longevity of posterior composite restorations: not only a matter of materials. Dent Mater 28, 87-101.

5. Opdam NJ, van de Sande FH, Bronkhorst E, Cenci MS, Bottenberg P, Pallesen U et al. (2014) Longevity of posterior composite restorations: a systematic review and meta-analysis. J Dent Res 93, 943-949.

6. Dietrich T, Losche AC, Losche GM, Roulet JF (1999) Marginal adaptation of direct composite and sandwich restorations in Class II cavities with cervical margins in dentine. J Dent 27, 119-128.

7. Dietrich T, Kraemer M, Losche GM, Roulet J (2000) Marginal integrity of large compomer Class II restorations with cervical margins in dentine. J Dent 28, 399-405.

8. Dietschi D, Spreafico R (1998) Current clinical concepts for adhesive cementation of tooth-colored posterior restorations. Pract Periodontics Aesthet Dent 10, 47-54.

9. Rocca GT, Krejci I (2007) Bonded indirect restorations for posterior teeth: from cavity preparation to provisionalization. Quintessence Int 38, 371-379.

10. Rocca GT, Gregor L, Sandoval MJ, Krejci I, Dietschi D (2012) In vitro evaluation of marginal and internal adaptation after occlusal stressing of indirect class II composite restorations with different resinous bases and interface treatments. "Post-fatigue adaptation of indirect composite restorations". Clin Oral Investig 16, 1385-1393.

11. Lefever D, Gregor L, Bortolotto T, Krejci I (2012) Supragingival relocation of subgingivally located margins for adhesive inlays/onlays with different materials. J Adhes Dent 14, 561-567.

12. Zaruba M, Gohring TN, Wegehaupt FJ, Attin T (2013) Influence of a proximal margin elevation technique on marginal adaptation of ceramic inlays. Acta Odontol Scand 71, 317-324.

13. Roggendorf MJ, Kramer N, Dippold C, Vosen VE, Naumann M, Jablonski-Momeni A et al. (2012) Effect of proximal box elevation with resin composite on marginal quality of resin composite inlays in vitro. J Dent 40, 1068-1073.

14. Frankenberger R, Hehn J, Hajtó J, Krämer N, Naumann M, Koch A et al. (2013) Effect of proximal box elevation with resin composite on marginal quality of ceramic inlays in vitro. Clin Oral Investig 17, 177-183.

15. Frese C, Wolff D, Staehle HJ (2014) Proximal box elevation with resin composite and the dogma of biological width: clinical R2-technique and critical review. Oper Dent 39, 22-31.

16. Geurtsen W, Spahl W, Leyhausen G (1998) Residual monomer/additive release and variability in cytotoxicity of light-curing glass-ionomer cements and compomers. J Dent Res 77, 2012-2019.

17. Goldberg M (2008) In vitro and in vivo studies on the toxicity of dental resin components: a review. Clin Oral Investig 12, $1-8$.
18. Tomakidi P, Fusenig NE, Kohl A, Komposch G (1997) Histomorphological and biochemical differentiation capacity in organotypic co-cultures of primary gingival cells. J Periodontal Res 32, 388-400.

19. Manojlovic D, Radisic M, Vasiljevic T, Zivkovic S, Lausevic M, Miletic V (2011) Monomer elution from nanohybrid and ormocer-based composites cured with different light sources. Dent Mater 27, 371-378.

20. Zingler S, Matthei B, Diercke K, Frese C, Ludwig B, Kohl A et al. (2014) Biological evaluation of enamel sealants in an organotypic model of the human gingiva. Dent Mater 30, 1039-1051.

21. Van Landuyt KL, Nawrot T, Geebelen B, De Munck J, Snauwaert J, Yoshihara K et al. (2011) How much do resinbased dental materials release? A meta-analytical approach. Dent Mater 27, 723-747.

22. Frankenberger R, Reinelt C, Petschelt A, Kramer N (2009) Operator vs. material influence on clinical outcome of bonded ceramic inlays. Dent Mater 25, 960-968.

23. Francisconi LF, Scaffa PM, de Barros VR, Coutinho M, Francisconi PA (2009) Glass ionomer cements and their role in the restoration of non-carious cervical lesions. J Appl Oral Sci 17, 364-369.

24. Lindberg A, van Dijken JW, Lindberg M (2007) Nine-year evaluation of a polyacid-modified resin composite/resin composite open sandwich technique in Class II cavities. J Dent 35, 124-129.

25. Kuper NK, Opdam NJ, Bronkhorst EM, Huysmans MC (2012) The influence of approximal restoration extension on the development of secondary caries. J Dent 40, 241-247.

26. Frese C, Wolff D, Zingler S, Krueger T, Stucke K, Lux CJ et al. (2014) Cytotoxicity of coated and uncoated fibrereinforced composites. Acta Odontol Scand 72, 321-330.

27. Spahl W, Budzikiewicz H, Geurtsen W (1998) Determination of leachable components from four commercial dental composites by gas and liquid chromatography/mass spectrometry. J Dent 26, 137-145.

28. Geurtsen W, Lehmann F, Spahl W, Leyhausen G (1998) Cytotoxicity of 35 dental resin composite monomers/additives in permanent $3 \mathrm{~T} 3$ and three human primary fibroblast cultures. J Biomed Mater Res 41, 474-480.

29. Zhang N, Ma J, Melo MA, Weir MD, Bai Y, Xu HH (2015) Protein-repellent and antibacterial dental composite to inhibit biofilms and caries. J Dent 43, 225-234.

30. Wu J, Weir MD, Melo MA, Xu HH (2015) Development of novel self-healing and antibacterial dental composite containing calcium phosphate nanoparticles. J Dent 43, 317-326.

31. Chatzistavrou X, Velamakanni S, DiRenzo K, Lefkelidou A, Fenno JC, Kasuga T et al. (2015) Designing dental composites with bioactive and bactericidal properties. Mater Sci Eng C Mater Biol Appl 52, 267-272. 